\title{
The Seasonal Distribution of Molluscan (Bivalvia and Gastropoda) Biodiversity in Riva Stream (Istanbul)
}

\author{
Nilay Dökümcü ${ }^{1}$ (D), Serap Koşal Şahin² (i)
}

Cite this article as: Dokumcu, N., \& Kosal Sahin, S. (2022). The seasonal distribution of molluscan (Bivalvia and Gastropoda) biodiversity in Riva stream (Istanbul). Aquatic Sciences and Engineering, 37(2), 69-73.

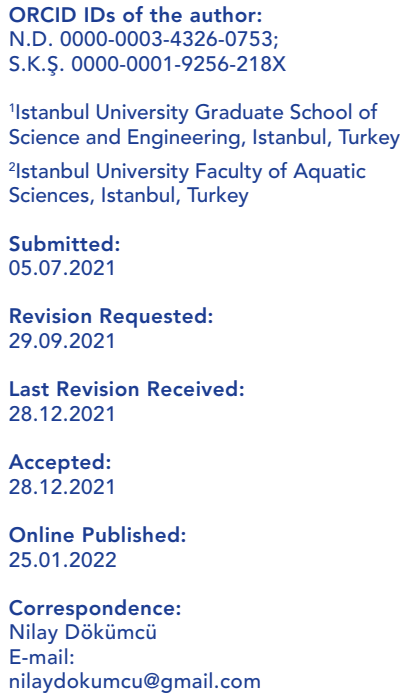

\begin{abstract}
Mollusk samples were collected between March 2018 and January 2019 through seasonal sampling at five stations [Riva (ST1), Kuzdere (ST2), Kanlıdere (ST3), Atdosun (ST4), Değirmendere (ST5)] of Riva Stream (Istanbul). In the study, 7,073 individuals, 7 taxa [1 species belonging to Prosobranchia (Bithynia sp.), 3 species belonging to Pulmonata (Planorbis planorbis (Linnaeus, 1758), Physella acuta (Draparnaud, 1805) and Gyraulus albus (O. F. Müller, 1774) and 3 species belonging to Bivalvia [Pisidium casertanum (Poli 1791), Pisidium amnicum (Muller, 1774) and Sphaerium corneum (Linnaeus, 1758)] were determined. Considering the dominance (\%) of taxa, Bithynia sp. was determined as the most dominant species among all stations $(5,479$ individuals $(77.46 \%)$ ). During sampling, various environmental variables [depth $(\mathrm{cm})$, width $(\mathrm{cm})$, flow rate $(\mathrm{m} / \mathrm{s})$, water temperature $\left({ }^{\circ} \mathrm{C}\right)$, dissolved oxygen (\%), $\mathrm{pH}$, conductivity $(\mu \mathrm{S} / \mathrm{cm})$, salinity $(\mathrm{ppm}), \mathrm{NH}_{4}-\mathrm{N}(\mathrm{mg} / \mathrm{L}), \mathrm{NO}_{3}-\mathrm{N}(\mathrm{mg} / \mathrm{L})$, $\mathrm{NO}_{2}-\mathrm{N}(\mathrm{mg} / \mathrm{L}), \mathrm{PO}_{4}-\mathrm{P}(\mathrm{mg} / \mathrm{L}), \mathrm{TP}(\mathrm{mg} / \mathrm{L})$ and TSS $\left.(\mathrm{g} / \mathrm{L})\right]$ were measured. The relationship between environmental variables and taxa was determined using Canonical Correspondence Analysis (CCA) using the Past Statistics Program, version 4.02. The clustering relationship between the five sampling stations and the unweighted pair group method (UPGMA) with arithmetic mean was shown.
\end{abstract}

Keywords: Gastropoda, Bivalvia, water quality, biodiversity, environmental variables

\section{INTRODUCTION}

Molluscs are a common macrobenthic invertebrate group of freshwater ecosystems (rivers, lakes, streams, shallow water etc.). They play significant roles in food webs and ecosystem equilibriums such as biofiltration, nutrient cycling and storage (Vaughn, 2017). Bivalves and gastropods are used as indicator organisms for biological monitoring and in hazard and risk assessment (Goldberg, 1986; Borcherding and Volpers, 1994).

Riva Stream, which is located on the Anatolian side of Istanbul, is a freshwater basin having a length of $70 \mathrm{~km}$. The stream is borne from Gebze, flows into the Black Sea through Beykoz and has approximately $859 \mathrm{~km}^{2}$ of drainage basin. In this study, five stations were selected including one main channel station [Riva (ST1)] and the other stations [ST2 (Kuzdere); ST3 (Kanlıdere); ST4 (Atdosun) and ST5 (Değirmendere)] were at the tributary (Table 1; Figure 1).

The aim of this study is to determine the molluscan fauna of Riva Stream for the first time and observe the environmental variables through biological monitoring.

\section{MATERIAL AND METHODS}

The field research was carried out between March 2018 and January 2019 at five stations (Riva, Kuzdere, Kanlıdere, Atdosun, Değirmendere). All samples were collected using a kicking method by a D-frame hand net which has a $0.5 \mathrm{~mm}$ mesh size. A $1 \mathrm{~m}^{2}$ area was selected on the field and samples were collected against the direction of the river's flow. The benthos 
Table 1. The sampling stations' coordinates.

\begin{tabular}{|c|c|c|}
\hline No & Station & Coordinates \\
\hline ST1 & Riva & $\begin{array}{l}\mathrm{N} 41^{\circ} 12^{\prime} 45.88^{\prime \prime} \\
\mathrm{E} 29^{\circ} 13^{\prime} 31.22^{\prime \prime}\end{array}$ \\
\hline ST2 & Kuzdere & $\begin{array}{l}\mathrm{N} 41^{\circ} 10^{\prime} 57.64^{\prime \prime} \\
\mathrm{E} 29^{\circ} 13^{\prime} 59.15^{\prime \prime}\end{array}$ \\
\hline ST3 & Kanlıdere & $\begin{array}{l}\mathrm{N} 41^{\circ} 07^{\prime} 08.30^{\prime \prime} \\
\mathrm{E} 29^{\circ} 16^{\prime} 09.80^{\prime \prime}\end{array}$ \\
\hline ST4 & Atdosun & $\begin{array}{l}\mathrm{N} 41^{\circ} 10^{\prime} 25.00^{\prime \prime} \\
\mathrm{E} 29^{\circ} 16^{\prime} 17.60^{\prime \prime}\end{array}$ \\
\hline ST5 & Değirmendere & $\begin{array}{l}\mathrm{N} 41^{\circ} 07^{\prime} 58.30^{\prime \prime} \\
\mathrm{E} 29^{\circ} 16^{\prime} 55.50^{\prime \prime}\end{array}$ \\
\hline
\end{tabular}

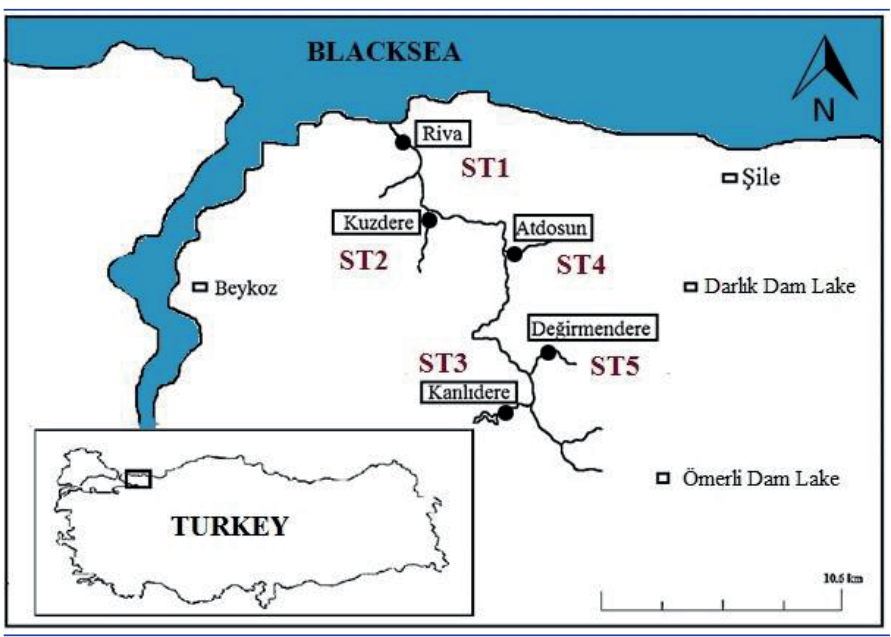

Figure 1. Study area.

material was fixed with ethyl alcohol in the field, eliminated via measured sieves under high-pressure water and preserved in $75 \%$ ethyl alcohol in the laboratory. Mollusks were identified at the species level by using the guidelines outlined by Schutt (1965), Macan (1969; 1977), Glöer (2002) and Oscoz (2011).

Dominance values and frequency of taxa were calculated according to individual number $\left[\mathrm{D}=(\mathrm{NA} / \mathrm{Nn})^{\star} 100\right]$ and $\left[\mathrm{F}=(\mathrm{Na} / \mathrm{Nn})^{\star 100}\right]$ $D$ : Dominancy, F: Frequency, NA: Individual number of " $A$ " taxon, $\mathrm{Na}$ : Sampling number of " $\mathrm{A}$ " taxon, $\mathrm{Nn}$ : All sampling/individual numbers) (Kocataş, 2008).

Some environmental variables (depth $(\mathrm{cm})$, width $(\mathrm{cm})$, flow rate $(\mathrm{m} / \mathrm{s})$, water temperature $\left({ }^{\circ} \mathrm{C}\right)$, dissolved oxygen $(\%), \mathrm{pH}$, conductivity $(\mu \mathrm{S} / \mathrm{cm})$, salinity (ppm)) were measured with multiparameter devices during sampling. Various chemical parameter values $\left(\mathrm{NO}_{3}-\mathrm{N}(\mathrm{mg} / \mathrm{L}), \mathrm{NO}_{2}-\mathrm{N}(\mathrm{mg} / \mathrm{L}), \mathrm{PO}_{4}-\mathrm{P}(\mathrm{mg} / \mathrm{L}), \mathrm{TP}(\mathrm{mg} / \mathrm{L})\right.$ and TSS $(\mathrm{g} / \mathrm{L})$ were analyzed according to the standard method (Boyd and Tucker, 1992). For measurements of $\mathrm{NH}_{4}-\mathrm{N}$ (mg/L) SM $4500 \mathrm{NH}_{3}$ $B$, the $F$ test method was followed.

The relationship between environmental variables and taxa was determined using Canonical Correspondence Analysis (CCA) via the Past Statistics Program, version 4.02. The clustering relationship between the five sampling stations by season and the unweighted pair group method (UPGMA) with arithmetic mean was shown.

\section{RESULTS AND DISCUSSION}

Biological Results: In this study, 7,073 individuals were examined in total, and it was found that 1 species belongs to Prosobranchia (Bithynia sp.), 3 species belong to Pulmonata (Planorbis planorbis (Linnaeus, 1758), Physella acuta (Draparnaud, 1805) and Gyraulus albus (O. F. Müller, 1774) and 3 species belong to Bivalvia [Pisidium casertanum (Poli 1791), Pisidium amnicum (Muller, 1774) and Sphaerium corneum (Linnaeus, 1758)] (Figure 2).

Considering the dominance (\%) of taxa, Bithynia sp. was determined as the most dominant taxon with $77.46 \%$, while $P$. casertanum (10.80\%) and P. acuta (9.12\%) were the second and third dominant taxa (Figure 3).

It was determined that the highest number of individuals at ST3 for all seasons and ST2 in Summer had a higher number of individuals from other stations. With 1,901 individuals, the ST3 Autumn season especially was the sampling with the highest number of individuals. While there were no bivalves at ST1 (all seasons), ST2 (Summer) and ST4 (Winter), ST1 had no mollusks in both Spring and Autumn.

According to the frequency (\%) of taxa, P. acuta was determined as $65 \%$, P. casertanum and Bithynia sp. as $60 \%$, and S. corneum as $10 \%$.

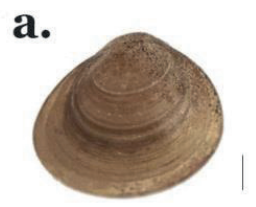

d.

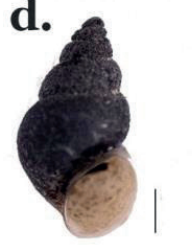

b.

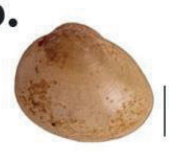

c.

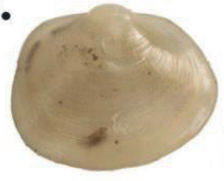

Figure 2. Mollusca diversity of Riva Stream [a- P.amnicum; b- $P$. casertanum; c- S. corneum; d- Bithynia sp.; e- $P$. planorbis; f- G. albus; g- P. acuta. Scale bars: $1 \mathrm{~mm}$ ].

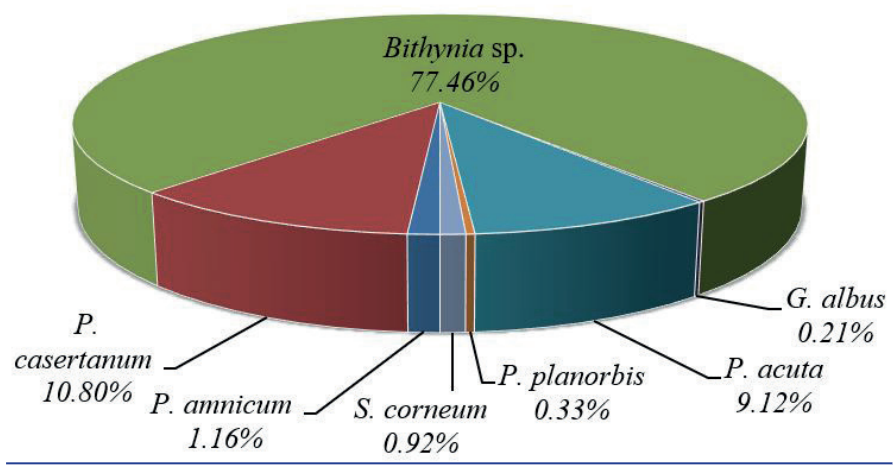

Figure 3. The dominance (\%) of taxa. 
In this study, 911 individuals belonging to 3 genera and 3 species were determined: Pisidium amnicum (Müller, 1774), P. casertanum (Poli, 1791), Sphaerium corneum (Linnaeus, 1758) of Bivalvia. P. amnicum was collected from ST2 (2 individuals), ST3 (54 individuals) and ST4 (26 individuals) in various seasons. S. corneum, with 65 individuals, was only collected from ST5 in Summer and Autumn. There were 435 individuals of $P$. casertanum collected from ST3 in all seasons except Winter and 279 individuals collected from ST4 in the same seasons. Twelve individuals were determined at ST2 except in Summer and 38 individuals at ST5 except in Autumn. The species identified are located within the range of distribution (Koşal Şahin and Yıldırım 2007; Kılıçaslan and Özbek, 2010; Koşal Şahin, 2013; Gürlek et al., 2019).

Of Gastropoda, 6,162 individuals belonging to 4 taxa of 3 families were determined (Bithynia sp., Planorbis planorbis (Linnaeus, 1758), Gyraulus albus (Müller, 1774), Physa acuta (Draparnaud, 1805). Bithynia sp. was determined as the taxon which has the highest number of individuals among all stations (5,479 individuals $(77.46 \%))$. The highest number of individuals belonging to the species was found at ST3 with 4,532 individuals. It was followed by ST2 with 933 individuals. The sum of individuals collected from ST2 and ST3, constitutes $99.7 \%$ of the total number of individuals of the species. While very few individuals were found at the other stations, there were no species found at ST5. Likewise,
G. albus was collected from all stations except ST4. The highest number of individuals ( 6 individuals) belonging to this species was found at ST1. P. planorbis was found at ST2 (8 individuals) in all seasons except Summer, while 1 individual at ST3 was found only in Summer. The species were found at ST5 (14 individuals) in all seasons. It was observed that the stations with the highest number of $P$. acuta were found at ST4 (411 individuals) and ST5 (214 individuals). It is known that individuals belonging to this species live on plants and ground mud in shallow waters in the region where vegetation is rich (Özvarol et al., 2004). Physa is one of the most tolerant genera to low oxygen conditions (Hawkes, 1997; Kırkağaç and Köksal, 2005). While other species identified are located within the range of distribution (Ertan et al., 1996; Özbek et al., 2004; Yıldırım, 2004; Koşal Şahin et al., 2017; Gürlek et al., 2019), G. albus was recorded for the first time in Istanbul.

Environmental variables: According to the average of physico-chemical values, depth values were between 20 and $47 \mathrm{~cm}$ and the width values were between 174 and 6,749 cm. It was seen that ST1 was quite wide compared to other stations. FR was between 0 and $0.85 \mathrm{~m} / \mathrm{s}$ and the sampling site of ST1 was stagnant, while other stations were more rapid. Water temperature results were between 12.6 and $14.9^{\circ} \mathrm{C}$. DO values were between 5.81 and $9.46 \mathrm{mg} / \mathrm{L}$. Considering the Criteria of Regulation on the Management of Surface Water Quality (2021), all stations ex-

Table 2. The individual number of taxa and the dominance (\%) and frequency (\%) in total.

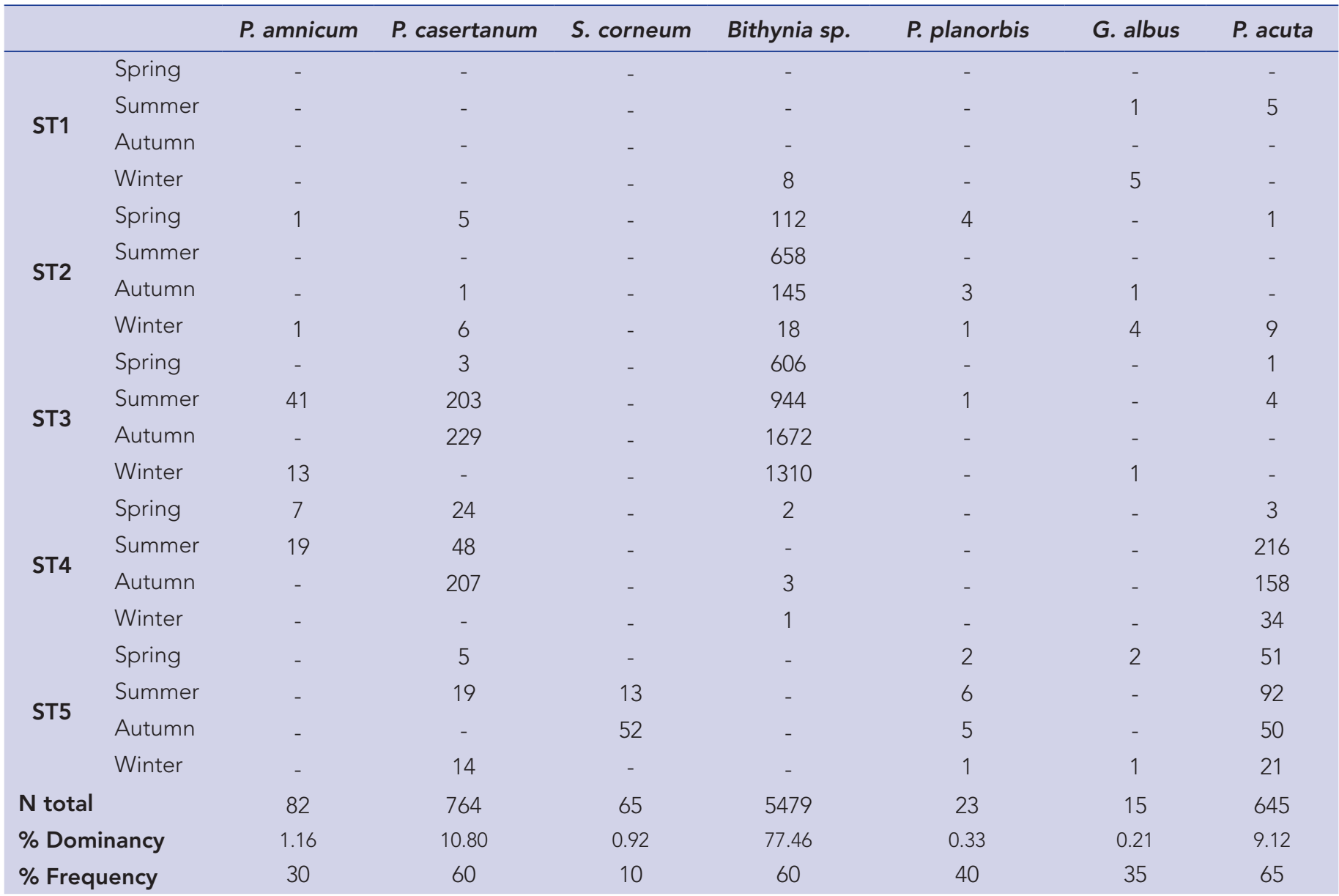


Table 3. The average of environmental variables of Riva Stream (Istanbul).

\begin{tabular}{|c|c|c|c|c|c|c|c|c|c|c|c|c|c|c|}
\hline & 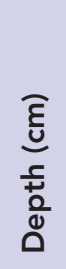 & $\begin{array}{l}\widehat{E} \\
\text { Ũ } \\
\frac{1}{+} \\
\frac{0}{3}\end{array}$ & $\frac{\tilde{n}}{\underline{\varepsilon}}$ & 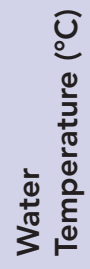 & 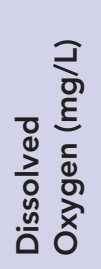 & I & 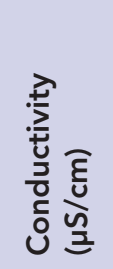 & 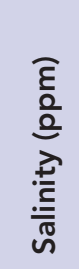 & 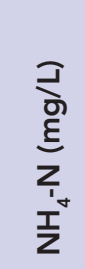 & 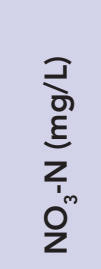 & 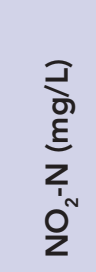 & 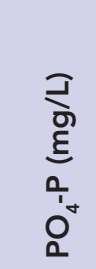 & 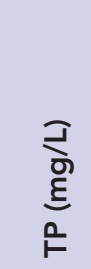 & 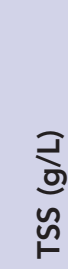 \\
\hline ST3 & 27 & 319 & 0.85 & 12.6 & 9.01 & 8 & 130 & 0.04 & 0.71 & 0.263 & 0.013 & 0.035 & 0.087 & 0.17 \\
\hline ST4 & 24 & 174 & 0.24 & 13.2 & 9.46 & 8.08 & 220 & 0.34 & $<0.5$ & 0.240 & 0.018 & 0.049 & 0.135 & 0.19 \\
\hline ST5 & 47 & 449 & 0.08 & 14.6 & 8.11 & 7.73 & 630 & 0.24 & $<0.5$ & 0.536 & 0.08 & 0.174 & 0.32 & 0.51 \\
\hline
\end{tabular}

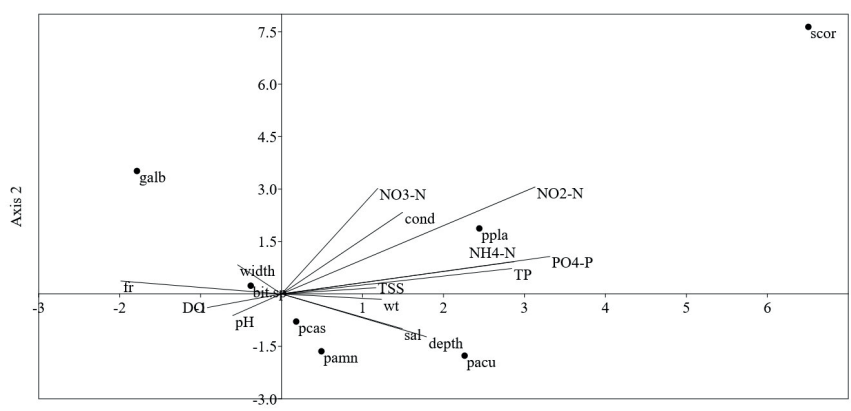

Axis 1

Figure 4. CCA triplot (Abbrv: pamn: P. amnicum, pcas: P. casertanum, bit.sp: Bithynia sp., galb: G. albus, pacu: P. acuta, ppla: P. planorbis, scor: S. corneum, wt: water temperature, sal: salinity, TSS: suspended solid, cond: conductivity, fr: flow rate).

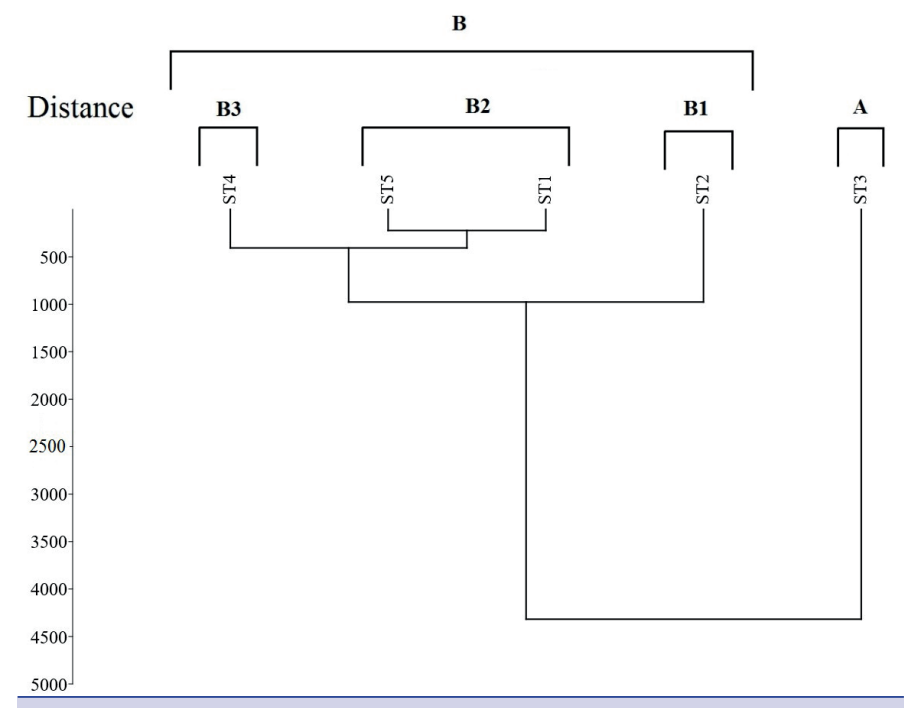

Figure 5. UPGMA Cluster Analysis based on mollusk diversity.

cept ST1 were Class I (>8), while ST1 was determined as Class III $(<6)$ in terms of DO. $\mathrm{pH}$ values were between 7.73 and 8.08 and measured within the specified range. Conductivity values were between 130 and 1,900 $\mathrm{S} / \mathrm{cm}$; according to the Criteria of Regulation on the Management of Surface Water Quality (2021), ST1 and ST2 were determined as Class III. The salinity values were between 0.04 and 1.31 ppm. ST1 is the main branch of Riva Stream and the closest station to the sea. Therefore, it was found to be the station with the highest salinity value. $\mathrm{NH}_{4}-\mathrm{N}$ values were between $<0.5$ and $4.99 \mathrm{mg} / \mathrm{L} ; \mathrm{NO}_{3}-\mathrm{N}$ was between 0.240 and $0.536 \mathrm{mg} / \mathrm{L}_{;} \mathrm{NO}_{2}-\mathrm{N}$ was between 0.013 and $0.083 \mathrm{mg} / \mathrm{L}$.

The highest $\mathrm{NH}_{4}-\mathrm{N}$ and $\mathrm{NO}_{2}-\mathrm{N}$ values were measured at ST1, while the highest $\mathrm{NO}_{3}-\mathrm{N}$ value was at ST5. According to the Criteria of Regulation on the Management of Surface Water Quality (2021), ST1 was determined as Class III in terms of $\mathrm{NH}_{4}-\mathrm{N}$, while ST2, ST4 and ST5 were measured as $<0.5 \mathrm{mg} / \mathrm{L}$.

$\mathrm{PO}_{4}-\mathrm{P}$ values were between 0.023 and $0.187 \mathrm{mg} / \mathrm{L}$ and TP between 0.087 and $0.367 \mathrm{mg} / \mathrm{L}$. According to the Criteria of Regulation on the Management of Surface Water Quality (2021), ST1 and ST5 were Class III in terms of $\mathrm{PO}_{4}-\mathrm{P}$ and TP values, while the other stations were Class I in terms of $\mathrm{PO}_{4}-\mathrm{P}$ and Class II in terms of TP.

TSS values were between 0.17 and $2.08 \mathrm{~g} / \mathrm{L}$. ST1 had the highest value as 2.08, and ST5 was determined as the second highest station. Selected environmental variables are shown in Table 3.

Statistical results: The relationship between individual mollusk numbers and environmental variables was determined by Canonical Correspondence Analysis (CCA) (Figure 4). In the CCA triplot shown, lines represent environmental variables and dots represent taxa. Eigen values of the first two axes were used for drawing the CCA triplot. Two axes, 51.79\% (1st Axis) and 25.51\% (2nd Axis), explain a total of $77.3 \%$. When the CCA triplot was examined, the species distributed parallel to the second axis and the water temperature value was closest to the second axis. According to this analysis, Bithynia sp. and flow rate appear to be closely related.

In addition, the similarity comparison of the stations according to the taxa found in Riva Stream stations was made (Figure 5). As a result of the UPGMA analysis, it is seen that the stream is divided into two sections (A-B) according to taxa. The third station in A was immediately separated from the B group according to the biological composition type they have. Three separate groupings are distinguished within group B (B1-B2-B3). Within the scope of similarity, ST1 and ST5 were identified as two similar stations. 


\section{CONCLUSION}

During the study area visits and according to the variables, it is seen that the stream is contaminated due to high levels of urbanization and domestic waste pressure. Increased measures are required to protect biodiversity and improve the water quality of Riva Stream.

Conflict of interests: There are no conflicts of interest to declare.

Ethics committee approval: Ethics committee approval is not required.

\section{Financial disclosure: -}

Acknowledgments: This study is based in part on doctoral research. We would like to thank the Graduate School of Science and Engineering; Unit of Scientific Research Projects and Inland Waters Department of Istanbul University (Project No.: 32254) for their valuable contributions.

\section{REFERENCES}

Borcherding, J. \& Volpers, M. (1994). The Dreissena-monitor -1st results on the application of this biological early warning system in the continuous monitoring of water quality. Water Science and Technology, 29: 199-201. [CrossRef]

Boyd, C. E. \& Tucker, C. S. (1992). Water Quality and Pond Soil Analysis for Aquaculture. Agricultural Experiment Station, Alabama.

Ertan, O.Ö., Yıldırım, M.Z. \& Morkoyunlu, A. (1996). The Mollusca species and their feeding models that distributes in Konne Spring (EğirdirTurkey). Second International Symposium on Aquatic Products in İstanbul, September 21-23 1996.

Gloer, P. (2002). Mollusca Süâwassergastropoden Nord-und Mitteleuropas, Bestimmungsschlüssel, Leben- sweise, Verbreitung. 73. Teil, 327 pp. Conch Books.

Goldberg, E.G. (1986). The mussel watch concept. Environmental Monitoring and Assessment 7: 91-103. [CrossRef]

Gürlek, M.E., Koşal Şahin, S., Dökümcü, N. \& Yıldııım, M.Z. (2019). Checklist of the Freshwater Mollusca of Turkey (Mollusca: Gastropoda, Bivalvia), Fresenius Environmental Bulletin, Volume 28 No. 4A/2019 P 2992-3013.

Hawkes, H.A. (1997). Origin and Development of the Monitoring Working Party Score System, Water Resources, 32(3), p 964-968. [CrossRef]
Kılıçaslan, I. \& Özbek, M., (2010). Contributions to the knowledge on the distribution of freshwater Mollusca species of Turkey, Review of Hydrobiology, 3,2: 127-144.

Kırkağaç, M. \& Köksal, G. (2005). Akarsularda Bentik Makroomurgasızların Su Kirliliğine Karşı Tepkilerinin Belirlenmesi: Biyotik ve Çeşitlilik Indekslerin Kullanımı, Ankara Üniversitesi.

Kocataş, A. (2008). Ekoloji ve Çevre Biyolojisi. Ege Üniversitesi Fen Fakültesi Ders Kitapları Serisi, 10. Baskı, 585pp., Bornova/İzmir.

Koşal Şahin, S. \& Yıldırım, M.Z. (2007). The Mollusk Fauna of Lake Sapanca (Turkey: Marmara) and Some Physico-Chemical Variables of Their Abundance, Turkish Journal of Zoology, Tubitak, 31: 47- 52.

Koşal Şahin, S. (2013). Aşağı Sakarya Nehri (Karasu) Mollusca Türleri ve Onları Etkileyen Bazı Fizikokimyasallar, Yunus Arastırma Bülteni (2): 11-19. [CrossRef]

Koşal Şahin, S., Dökümcü, N. \& Özuluğ, O. (2017). The Mollusk Fauna of Istranca Stream (Terkos-Istanbul) And Some Physico-Chemical Variables of Their Abundance, Fresenius Environmental Bulletin, Vol.26, Pp.1026-1041.

Macan, T. (1969). A Key to the British Fresh and Brackish Water Gastropods, Freshwater Biological Association, Scientific Publication, Germany, Third Edition.

Macan, T. (1977). A Key to the British Fresh and Brackish Water Gastropods. Freshwater Biology, Association Scientific Publication. No: 13.

Oscoz, J., Galicia, D. \& Miranda, R. (ed.) (2011). Identification Guide of Freshwater Macroinvertebrates of Spain, Springer, London. 153 pp. ISBN: 978-94-007-1553-0. [CrossRef]

Özbek, M., Ustaoğlu, M.R., Balık, S. \& Sarı, H.M. (2004). Mollusca Fauna of Some Lakes in The Western Black Sea Region, $11^{\text {st }}$ National Malacology Congress, E. U. Faculty of Fisheries, Bornova, İzmir.

Özvarol, Z.A.C., Gümüs, E. \& Begburs, C.R. (2004). Sarısu (Antalya) Deresinin Mollusca Faunası Üzerine Bir Ön Çalışma, Tr. J. of Aquatic Life, 2, 33-40.

Regulation on Surface Water Quality Management (2021). Ministry of Agriculture and Forestry, Official Gazette number: 31513. Ankara, Turkey.

Schutt, H. (1965). Zur Systematik und Okologie Turkischer Susswasserprosobranchier. Zoologische Mededelingen, Deel, 41 (3): 4371.

Vaughn C. (2017). Ecosystem services provided by freshwater mussels. Hydrobiologia 810(1): 15-27. [CrossRef]

Yıldırım, M.Z. (2004). The Gastropods of Lake Eğirdir. Turkish Journal of Zoology. 28, 97-102. 